\title{
State Policy Priorities for Economic Security Provision among Processing Industries
}

\author{
Melnikov Alexander Borisovich", Snimshikova Irina Viktorovna ${ }^{1}$, Trysyachny Vladimir Ivanovich ${ }^{1}$, Aydaeva \\ Sakina Agaverdievna ${ }^{2} \&$ Rudenko Vladimir Valentinovich $^{3}$ \\ ${ }^{1}$ Kuban State Agrarian University, Krasnodar, Russia \\ ${ }^{2}$ Dagestan State Technical University, Makhachkala, Russia \\ ${ }^{3}$ Stavropol Cooperation Institute (Branch), Belgorod University of Cooperation, Economics and Law, Stavropol, \\ Russia \\ Correspondence: Melnikov Alexander Borisovich, Kuban State Agrarian University, Krasnodar, Russia. E-mail: \\ russia@prescopus.com
}

Received: April 19, 2017

doi:10.5539/jpl.v10n3p112
Accepted: April 27, $2017 \quad$ Online Published: June 1, 2017

URL: https://doi.org/10.5539/jpl.v10n3p112

\begin{abstract}
The Russian specificity of processing industry functioning does not allow domestic products to compete on an equal basis with imported analogues, not only at external, but also at the domestic market, which makes a negative impact on the level of economic security. In this context, the harmonization of industrial and trade policies can be viewed as the combination of individual development institutions aimed at the search of external and internal sources of investment resources, as well as the development of import-substituting industrialization policy trends. The results of modeling using the modified Grossman-Helpman model demonstrate that the hypothesis about the dependence of import tariff rate on the strength of industrial lobby groups is not confirmed. Consequently, the tariff foreign trade policy of Russia is a fragmentary one and does not develop the unified principles and priorities for key processing industry support. In this regard, the main task is the development of universal tools that allow to increase the level of business entity adaptability to the increased volatility of endogenous and exogenous factors negatively influencing the level of economic security among industrial complexes.
\end{abstract}

Keywords: economic security, manufacturing industry, trade policy, Grossman-Helpman model

\section{Introduction}

One of the main tools to ensure the required level of economic security in modern conditions is the transition to the strategy of "import-substituting industrialization", which facilitates the transformation of the economy structure from labor-intensive and energy-intensive industries in favor of capital-intensive and knowledge-intensive industry development. The Russian specifics of innovation cluster development is characterized by relatively low labor productivity, which predetermines the low investment attractiveness of projects, the implementation of which are possible within the framework of the import substitution policy. Also, the low quality of manufactured goods makes a negative impact on the level of economic security, which does not allow domestic products to compete with imported counterparts on an equal basis, not only at external markets, but also at the domestic market.

Under these conditions, the main tasks that needed to be addressed by the states that use the import substitution strategy are the following ones: "changing the structure of the economy sectors and the increase of labor productivity in line with the best practices of developed countries dominated by high-tech sectors at the replacement of imported goods with the goods produced within the country" [3].

During the early stages the policy of import substitution is the creation of conditions for the development of new industries. The key tool here is the trade policy of a state, namely:

- the introduction of protective import and export tariffs;

- the branch preferences for national manufacturers and foreign companies-importers; 
- the preferential conditions for the import of raw materials and the materials used in the manufacturing sectors of industry.

In the historical perspective, the achievement of an acceptable level of economic security is impossible without the development of strategic priorities in the implementation of the industrial policy of import substitution, the implementation of which requires more active use of the following tools:

- the increasing of credit resource availability by using the funds of state development banks or by subsidizing the interest rate on loans;

- the use of tax incentives to increase the innovation activity of economic entities;

- a direct or an indirect state participation in the implementation of priority investment projects, including the projects within the framework of public-private partnership

- the development of transport, information and production infrastructure.

Obviously, the growing of domestic industry competitiveness makes a positive influence on the level of economic security at the meso- and macrolevel and in the long-term perspective leads to a gradual reduction of a state and the full-fledged development of market principles for the operation of key industrial complexes. Otherwise, as N. Volchkova notes: "The strategy of import substitution that turns into permanent subsidization of the industry leads to significant risks in one form or another due to the lack of incentives for the achievement of economic and technological efficiency in production" [1].

\section{The Policy of Import Substitution as the Factor of Industry Economic Security Strengthening}

The effectiveness of import-substituting industrialization policy according to the experience of most countries is an ambiguous one. A number of authors note the negative effect on economic growth due to the distortion of market incentives $[8,11]$. Most often, this occurs when new enterprises are created, when total investments exceed the value of the discounted cost of production, i.e. there is the production of negative added value.

Large-scale spending of budgetary funds can lead to a fiscal imbalance and to the budget deficit increase, which will increase the negative effect of co-financing program reduction for investment projects in the long run, and it may lead to a debt crisis at the macro level. However, as the example of India shows, where the policy of import substitution was conducted from the 1950 s to the 1980 s, when a threat to the stability of the functioning fiscal system occurs during the implementation of large-scale state support tools, it can be minimized through the use of discretionary macroeconomic policy measures, which can reduce the amount of budget deficit [13].

In accordance with empirical research, the policy of import substitution can lead to increased labor productivity [13], increased competitiveness [8] and the emergence of new industrial complexes [9]. This is evidenced by the experience of such countries as Mexico (1950's), Argentina (1970's), Brazil (1980's) and Turkey (1990's).

From the point of view of economic security provision, the state support for priority and often uncompetitive industries leads to inefficient spending of budgetary funds, which could provide an additional multiplier effect in competitive sectors of the economy. In this regard, state support for such industries is not expedient in a long run. However, in the long term, this will lead to the increase of the national economy dependence on foreign technologies and, thus, to the achievement of economic security critical levels. A competent combination of trade and industrial policy tools will help to create "national champions" and competitive industries at global markets.

Recognizing the validity of the criticism concerning the effectiveness of import substitution policy, for example in Latin America, the disadvantage of most strategies is that they did not take into account the potential opportunities and existing competitive advantages of individual territorial-sectoral complexes, since the decisions were often taken within political aspects, and They were not based on economic analysis and capacity assessment. One should also take into account the institutional factors that influence the development of effective trade and industrial policies in order to ensure economic security.

The resulting indicator of a positive relationship between institutional development and the level of economic security is investment activity in certain industry complexes, as entrepreneurs are always extremely sensitive to risk, the magnitude of which depends on the quality of an institutional environment. Developed institutions determine not only the scale of financial resources, but also the time horizons of investment that are laid by economic agents in their development strategies.

Thus, based on these prerequisites concerning the provision of an acceptable level of economic security for an industrial complex, industrial and trade policy can be regarded as a set of specific development institutions and the evaluation of individual tool application appropriateness, which predetermines the existence of the 
relationship between industrial and trade policies with a variety of other factors. J. Sachs noted: "On the one hand, the variety of some institutions provides an industrial policy as such, and, on the other hand, the totality of other institutions is the ground for the implementation of individual instruments" [14].

The provision of an acceptable level of economic security in processing industry, especially with regard to the elimination of the domestic production base technological backwardness, is a key task of the state policy in the field of import substitution.

World experience shows that there is no universally accepted practice of strategy development for import-substituting industrialization. This is explained by the degree of openness and institutional development of national economies, the development priorities, etc.

The main conclusions that economists come to can be grouped into two key categories i.e. "for" and "against" and they are the following ones.

Arguments "against".

1) There is a negative transformation of investment incentives. This is related to the fact that entrepreneurs are more interested to implement the projects, where the cost of production factors may exceed the cost of manufactured products, i.e. there is a negative added value.

2) An active import substitution state policy which is highly demanding can lead to the increase of fiscal imbalances and the risks of national economy destabilization through the growth of external debt and a sharp reduction of foreign investment.

3) The decrease of public welfare due to the weakening of the national economic space integration into the global economy and an insufficient participation in the international labor differentiation.

Arguments "for".

1) The state policy of import substitution can become the catalyst to accelerate the growth rates of production in key industrial complexes. The empirical analysis in a number of works proves [8] that the growth of labor productivity in Latin America with an active performance of import substitution policy was higher than in the countries of South-East Asia, where the emphasis was on export-oriented industry development.

2) Some authors argue that the policy of import substitution can not be a priori incorrect $[3,12]$. The theoretical models demonstrate that this policy can be an effective one if certain prerequisites and reservations are observed. A number of countries experienced lower economic growth rates due to the under-investment of the production sector and insufficient government support.

Thus, the interrelation of an effective state policy for the industrial sector growth stimulation and the level of institution development shows that it is possible to achieve the necessary level of economic security among individual sectors only on the basis of external and internal sources of investment resource search. The absence of a consistent, predictable and transparent industrial and trade policy led to the fact that most of the state initiatives proved to be ineffective and eventually unclaimed (the development of unrelated programs for the strategic development of industry in general and individual industries, the creation of vertically integrated structures to stimulate innovation, the creation of specialized peculiar economic zones, etc.). In this regard, the development of an effective policy of import substitution requires a more detailed analysis of investment activity in manufacturing industry and the development of priorities for a state economic policy.

\section{Analysis of Investment Activity in Respect of Processing Enterprises}

To assess the need and the feasibility of an import substitution policy, let's conduct investment activity analysis in the manufacturing industry starting from 2005. First of all, for the purposes of technical and technological component determination concerning economic security, we will analyze the dynamics of investments, the state of fixed assets and the efficiency of production.

The analysis of investment dynamics in manufacturing industry shows that this indicator is very volatile and highly dependent on an economic situation [2]. As can be seen from Table 1, the crisis of 2008 had a sharp drop in investment activity. Thus, the decrease of investment in fixed capital within the constant prices in 2009 made $16.9 \%$ as compared to 2008 , although it made $15.2 \%$ in national economy. 
Table 1. Dynamics of some indicators in processing industry

\begin{tabular}{|c|c|c|c|c|c|c|c|c|c|}
\hline \multirow[t]{2}{*}{ Indicator } & \multicolumn{9}{|c|}{ Years } \\
\hline & 2005 & 2008 & 2009 & 2010 & 2011 & 2012 & 2013 & 2014 & 2015 \\
\hline $\begin{array}{l}\text { Volume of shipped goods, billion rubles. (the } \\
\text { prices of 2005) }\end{array}$ & 6742,8 & 8250,4 & 7192,3 & 7741,2 & 8114,7 & 8302,6 & 8317,4 & 8505 , & 8170,8 \\
\hline $\begin{array}{l}\text { Volume of fixed assets, bln. rub. (the prices of } \\
\text { 2005) }\end{array}$ & 2560,4 & 2814,8 & 3006,7 & 2950,0 & 3101,4 & 3294,2 & 3704,8 & 4105 & 4184,3 \\
\hline $\begin{array}{l}\text { Investments in fixed assets, bln. rub. (the prices } \\
\text { of 2005) }\end{array}$ & 498,4 & 706,4 & 587,4 & 590,1 & 604,4 & 673,2 & 698,1 & 697,4 & 661,2 \\
\hline Depreciation of fixed assets (FA), $\%$ & 47,1 & 45,6 & 45,7 & 46,1 & 46,7 & 46,8 & 46,8 & 46,9 & 48,0 \\
\hline The share of completely worn out FA, $\%$ & 17,0 & 13,2 & 12,8 & 12,8 & 12,9 & 13,5 & 13,3 & 14,0 & 14,4 \\
\hline Investment ratio to $\mathrm{FA}, \%$ & 18,2 & 23,8 & 17,6 & 18,3 & 18,6 & 18,8 & 17,3 & 16,4 & 14,9 \\
\hline
\end{tabular}

Further recovery of Russian economy in terms of GDP exceeded the pre-crisis figures of 2007, but the dynamics of investment in fixed assets did not show a sustainable growth. Only in 2013 this indicator almost reached the level of 2008, and it decreased by $5.5 \%$ in 2015 . The growth of investments in the manufacturing industry was from 498 billion rubles up to 661 billion rubles, and the volume of fixed assets increased 1.5 times to 4,200 billion rubles. This does not allow to speak about the presence of investment growth in processing industry. In our opinion, the industrial complex is on the verge of an investment crisis, and the technical and technological component of economic security level exceed the threshold values by some indicators. This conclusion can be drawn on the basis of fixed assets depreciation rate analysis and the share of investments in fixed assets [4]. Although the share of fully worn-out fixed assets was $14.4 \%$ by 2015 and remained practically unchanged from 2008, the share of worn-out funds began to grow from 2015 and reached $48.0 \%$, while the share of investments in fixed capital decreased from $23.8 \%$ in 2008 to $14.9 \%$ in 2015 .

As can be seen the main problem of economic security level increase in the processing industry is associated with low investment activity of economic entities and the significant depreciation of fixed assets. The extrapolation of existing trends shows that during the next three years the dynamics of investments will remain negative or will stagnate, hence the depreciation index of fixed assets will exceed $50 \%$. This will make an adverse impact on the competitiveness of the national manufacturing industry, not only at the global, but also at the domestic market, since modern products can't be produced with the use of obsolete equipment. In this regard, the industrial policy aimed at import-substituting industrialization requires the investment activity increase in industry.

A comparative analysis of the national economy investment competitiveness, which can be estimated as the ratio of GDP growth rates to the index of fixed capital accumulation with the countries of Western Europe, also confirms the conclusion about the continuing technical and technological gap (Table 2). GDP growth is possible only in the conditions of fixed capital accelerated update, including the manufacturing industry, but during the last four years the value of the analyzed indicator decreased and reached the average European level with higher depreciation of fixed assets in national economy.

Table 2. Gross accumulation of fixed capital in Russia and Western countries, \% of GDP

\begin{tabular}{lcccccccc}
\hline Country & \multicolumn{7}{c}{ Years } \\
\cline { 2 - 8 } & 2005 & 2008 & 2009 & 2010 & 2011 & 2012 & 2013 & 2014 \\
\hline Great Britain & 18,0 & 17,9 & 16,1 & 16,1 & 16,1 & 16,2 & 16,9 & 17,5 \\
Germany & 19,1 & 20,3 & 19,1 & 19,3 & 20,2 & 20,0 & 19,4 & 19,3 \\
France & 21,7 & 23,6 & 22,0 & 22,1 & 22,4 & 22,5 & 22,3 & 22,1 \\
Spain & 29,9 & 29,2 & 24,3 & 23 & 21,4 & 19,7 & 19,1 & 19,7 \\
Italy & 21,1 & 21,2 & 20,0 & 19,9 & 19,6 & 18,6 & 17,0 & 16,3 \\
Russia & 20,0 & 25,5 & 28,9 & 22,6 & 25,0 & 24,8 & 22,8 & 20,3 \\
\hline
\end{tabular}


First of all, one of the main reasons for the low investment activity of industrial enterprises is the introduction of financial sanctions against Russian banks, which resulted in a sharp increase of borrowed fund cost and made them practically inaccessible for the enterprises in the processing industry. For example, in 2015 the return on assets and sales was below the interest rate on the loan by $3.4 \%$ and $11.1 \%$, respectively, which made almost $16 \%$ on the average. It should be noted that the sharp rise of interest rates is also associated with the policy Russian Federation Central Bank, which increased the key rate by 6.5 percentage points since the end of 2014. And this reduced the availability of loans by almost half and deepened the negative trends in processing industry.

Table 3. Return on assets and interest rate in processing industry, $\%$

\begin{tabular}{lccccccccc}
\hline \multicolumn{1}{c}{ Indicator } & \multicolumn{10}{c}{ Years } \\
\cline { 2 - 10 } & 2005 & 2008 & 2009 & 2010 & 2011 & 2012 & 2013 & 2014 & 2015 \\
\hline Return on sales & 15.3 & 17.1 & 13.4 & 14.8 & 13.2 & 10.7 & 8.8 & 9.9 & 12.4 \\
Return on assets & 11.9 & 8.6 & 6.1 & 8.2 & 8.4 & 8.1 & 4.5 & 2.9 & 4.7 \\
Loan interest rate & 10.7 & 12.2 & 15.3 & 10.8 & 8.5 & 9.1 & 9.5 & 11.4 & 15.8 \\
\hline
\end{tabular}

Analyzing the impact of investment activity in processing industry on the level of economic security, it is necessary to assess the key negative factor, namely, the sanctions imposed on Russia.

The import of foreign equipment for the purpose of fixed asset update became practically impossible for a number of processing industry branches. Taking into account the level of dependence on the use of imported equipment, which reached $35-40 \%$ on the average, almost complete absence of domestic analogues the thesis on the need for an integrated industrial and trade policy development to ensure the necessary level of economic security is confirmed. One of the key priorities here is the development of import-substituting industries, especially with respect to investment goods. An effective tool for the achievement of set goals can be the transformation of the tariff policy in relation to imported products.

\section{Trade Policy Development Model in Relation to Import Tariffs for Processing Industry Products}

At present, one may distinguish two basic theoretical approaches that explain the specifics of tariff development for imported goods, taking into account endogenous factors [11]: taking into account the possibilities of sectoral lobbying and their absence.

The most common model is Grossman and Helpman model [10]. In their work "Protectionism for sale" the authors analyzed the processes of tariff policy development with respect to imported goods in the sectoral context of an open economic system. The main author's idea was that sectoral interests are developed in groups and promoted by offering "cash contributions" to the acting authorities in exchange for the growth of sectoral import tariffs. Consequently, unlike a number of other works [15], sectoral lobbyists do not try to influence the outcome of elections, but focus their attention strictly on trade policy. The formalization of the model consists in the analysis of interaction specifics between consumers, industry lobbyists and the authorities that maximize the corresponding utility functions.

The forms of interaction are presented by a two-stage non-cooperative game. The first stage is characterized by the fact that an industrial lobbyist informs the authorities about his preferences, i.e. about the amount of "cash contribution" offered in exchange for a specific tariff on imported goods in his industry and related ones. The main prerequisite is that sectoral lobbyists know the parameters of the authority utility functions and take into account specific preferences developing their proposal. Consequently, the function of sectoral utility consists of two components:

$$
V_{i}=W_{i}-C_{i}
$$

where $C_{i}$ - the contribution amount of the i-th industry;

$W_{i}$-is the aggregate sectoral utility of a lobby group, which is developed from the labor income $l_{i}$, the income from the capital $\pi_{i}\left(p_{i}\right)$, which depend on the scale of prices, the consumer surplus $a_{i}{ }^{*} N^{*} s(p)$ and customs revenues, $a_{i}{ }^{*}{ }^{*} r(p)$, distributed evenly by the authorities among economic agents:

$$
W_{i}(p)=l_{i}+\sum_{i=1}^{n} \pi_{i}\left(p_{i}\right)+a_{i}-N[r(p)+s(p)]
$$

where $a_{i}$ is the share of the population that owns capital in the i-th industry and makes the part of the 
corresponding special interest group. During the second stage, after the receiving of a proposal from an interest group, the government sets the tariffs in the sectoral way so as to maximize its own utility function. In this case, the authorities establish different weights for public welfare, depending on the contributions received from each interest group that forms the target function of authorities:

$$
G=\sum_{i \in L} C_{i}(p)+a W(p), a \geq 0,
$$

where $\sum_{i \in L} C_{i}(p)$ - the sectoral amount of contributions provided by an interest group;

$W(p)$ - the total social welfare without taking into account the influence of lobbyists;

$a$ - the weight factor established by the government in respect of public welfare, taking into account lobbying contributions.

The results of the simulation demonstrate that the interindustrial differentiation of the aggregate import tariff in the equilibrium state depends on the degree of a sectoral lobby organization. The indicator of the function $\mathrm{I}=1$ if there is an industrial lobbying organization that offers "cash contributions" to authorities, otherwise $\mathrm{I}=0$. Also, the tariff policy for imported goods depends on the ratio of industrial output to imports (z) and the values of elasticity factor concerning the volumes of imported goods $\left(\mathrm{t}_{\mathrm{i}}\right)$ to tariff rates (e). The average size of sectoral tariffs also correlates with structural parameters, for example, with the value for public welfare authorities (a), as well as by the degree of a lobbying group influence $\left(a_{L}\right)$ :

$$
\frac{t_{i}}{1+t_{i}}=\left(\frac{I_{i}-a_{L}}{a+a_{L}}\right) *\left(\frac{z_{i}}{e_{i}}\right) .
$$

In accordance with the final expression for the industries that have a lobbying group (an organized branch), the authorities set an appropriate tariff for imported goods, and for the industries that do not have a lobbying influence (an unorganized industry) an import subsidy is set. At that, the higher value of elasticity coefficient for imported goods and the specific gravity of imports have an inverse correlation with the value of import duty rates for both types of industries. The main reason for this is that the higher import and sectoral elasticity with respect to import, the greater is the loss of public welfare in the event of high tariff rate or sector subsidy setting.

The empirical studies of the decision-making process evaluation on the rate of import customs duties based on Grossman-Helpman model for Russia were conducted by Afontsev in [6], where the author analyzes a number of factors potentially affecting the tariff policy. The simulation results demonstrate that the basic hypotheses of Grossman-Helpman model are not confirmed. Thus, Afontsev concludes that the size of ownership concentration in the sectors and the share of imported goods in the total output are of basic importance. These factors are directly correlated with the size of import tariffs.

For the purposes of import substitution policy effectiveness evaluation in the processes of industry economic safety increase, Knobel's work [5] should be mentioned, in which the author examined the influence of sectoral import tariff rate values on the proportion of three largest companies in the industry, the ratio of import to output and other factors. According to the results of the study, the value of import duty rates has a negative correlation with the concentration of ownership, the specific gravity of imports and the number of workers.

Thus, the solution of the problem concerning the harmonization of trade and industrial policy and the provision of the necessary level of technical and technological safety for processing industry is possible on the basis of Grossman-Helpman model use with a modified set of factors that take into account Russian specifics.

\section{Simulation Results and Conclusions}

In order to assess the appropriateness of tariff policy tool use to improve the level of economic safety for manufacturing industry, an empirical test was carried out concerning the basic equation of Grossman-Helpman model and the hypothesis that the tariff rates of import customs duties depend on the concentration of production in the processing industry (the presence of a lobbying group), the share of imported products at the market, the cost of imported raw materials and supplies, as well as the share of investments aimed at the renewal of fixed assets.

In accordance with the theoretical conclusions of the Grossman-Helpman model in this model specification, the parameter for the variable characterizing the presence of an industrial lobby should be a negative one [7]. This is due to the fact that the industries with a strong lobby have the opportunity not only to promote the establishment of import duty high rates in their industry, but also to lobby low tariffs in related industry complexes in which they are consumers.

The coefficient $\beta_{1}+\beta_{2}$ for the industries that have a lobby is a positive one in accordance with the 
Grossman-Helpman model [11]. This is due to the fact that the higher the industry output in these industry complexes, the greater is the overall gain from tariff increase for these producers. However, the greater the volume of product imports in an industry with a high concentration of production, the greater is the impact of tariff increase on public welfare. Thus, if a state cares about the population welfare, the more it is interested in the setting of lower tariff rates.

In order to conduct the econometric analysis, we used the statistics according to the level of tariffs in 2015 , as well as the necessary array of statistical information in the context of processing industry and the main groups of investment goods. The descriptive statistics of the source data are presented in Table 4.

Table 4. Descriptive statistics of the source data array

\begin{tabular}{lcccc}
\hline Variable & Median & St. dev. & Minimum & Maximum \\
\hline Import customs duty rate, \% & 9,5 & 4,2 & 0 & 16,3 \\
Share of imported products at the market, \% & 22,1 & 20,9 & 3,5 & 72,6 \\
Specific weight of costs for imported raw materials and & 18,3 & 10,7 & 6,2 & 38,1 \\
materials, \% & & & & \\
Share of investments in fixed assets, \% & 51,1 & 14,4 & 21,5 & 70,2 \\
Share of three largest firms, \% & 67,4 & 31,2 & 9,1 & 100,0 \\
\hline
\end{tabular}

In 2015 the average rate of import customs duty was 9.5\%. Maximum rates are applied to motorcycles (16.4\%), as well as to lamps and lighting equipment $(16.3 \%)$. At the same time, the share of three largest firms at the market for these types of products makes $100.0 \%$ and $24.7 \%$, respectively. It should be noted that the maximum concentration of production (100.0\%) is observed in the industries that are fundamental ones to provide the required level of an industrial complex economic security, namely: the production of lathes, metal cutting and programmable machines, the equipment for the production of semiconductor products, electrical equipment and circuits, etc. The minimum potential for lobbying opportunities is observed in light industry, where the level of production concentration ranges from $9.1 \%$ to $14.8 \%$ due to heavy industry. The average value of this indicator makes $67.4 \%$. Metallurgy also has the maximum volume of investment in fixed assets, which amounted to $70.2 \%$. A negative trend is the fact that minimal investment activity is observed in the production of electronic and optical equipment (24.3\%). This indicator is less only in the manufacture of leather goods and shoes (21.5\%). The specific weight of costs on imported raw materials and materials in processing industry makes $18.3 \%$ on the average, the minimum makes $6.2 \%$ in metallurgy and the maximum makes $38.1 \%$ in the production of machinery and equipment.

The parameterization of the Grossman-Helpman equation is based on the use of the standard least squares method (Table 5).

Table 5. Model specification evaluation results

\begin{tabular}{|c|c|c|c|}
\hline Parameters & Value & Standard error & $P>|t|$ \\
\hline \multicolumn{4}{|c|}{ Industries with the maximum share of the three largest firms } \\
\hline$\beta_{1}$ & $-0,488$ & 0,403 & 0,024 \\
\hline$\beta_{2}$ & 0,812 & 0,392 & 0,060 \\
\hline Free member & 5,877 & 0,518 & 0,000 \\
\hline \multicolumn{4}{|c|}{$\mathrm{R}^{2}=0,198, \mathrm{~F}=3,192, \mathrm{P}>\mathrm{F}=0,094$, amount of observations: 46} \\
\hline \multicolumn{4}{|c|}{ Industries with maximum import tariffs } \\
\hline$\beta_{1}$ & $-0,912$ & 0,295 & 0,000 \\
\hline$\beta_{2}$ & 6,140 & 2,836 & 0,029 \\
\hline Free member & 7,774 & 0,544 & 0,000 \\
\hline \multicolumn{4}{|c|}{$\mathrm{R}^{2}=0,421, \mathrm{~F}=5,48 \mathrm{P}>\mathrm{F}=0,0162$, amount of observations: 29} \\
\hline
\end{tabular}




\begin{tabular}{cccc}
\hline \multicolumn{4}{l}{ Industries with a minimal share of imported products at the market } \\
\hline$\beta_{1}$ & $-0,0664$ & 0,032 & 0,037 \\
$\beta_{2}$ & 0,138 & 0,042 & 0,026 \\
Free member & 5,041 & 0,251 & 0,000 \\
$\mathrm{R}^{2}=0,104, \mathrm{~F}=3,87, \mathrm{P}>\mathrm{F}=0,0126$, amount of observations: 61 & \\
\hline \multicolumn{4}{r}{ Industries with a minimum share of costs on imported raw materials and materials } \\
\hline$\beta_{1}$ & $-0,219$ & 0,501 & 0,027 \\
$\beta_{2}$ & 0,904 & 2,489 & 0,040 \\
Free member & 3,118 & 0,479 & 0,000 \\
$\mathrm{R}^{2}=0,187, \mathrm{~F}=3,24, \mathrm{P}>\mathrm{F}=0,0133$, amount of observations: 72 \\
\hline \multicolumn{4}{r}{}
\end{tabular}

The simulation results show that the hypotheses valid for the Grossman-Helpman model are practically not fulfilled for processing industries, and the obtained results obtained are consistent with the theoretical assumptions of the model rather weakly. Thus, the concentration index makes an impact on the size of import tariffs and is statistically significant only for metallurgy.

The main conclusions that we can derive from our analysis are in the fact that the indicators characterizing the level of economic safety for processing industries can not be used as approximants. On the one hand, this may be related to the fact that the method of least squares was used in econometric analysis, which assumes the linear nature of the resulting variable dependence on the factor ones. On the other hand, the tariff policy of the state is fragmentary one and does not develop the unified principles and priorities for key industry support. The main reasons for this may be a critical dependence on imported technologies and equipment. So, the setting of high tariffs on imported equipment can make it very expensive to domestic enterprises, and the absence of Russian analogues exacerbates the problem. This confirms the need to establish a balanced trade and industrial policy once again with regard to the raise of economic safety level for the manufacturing industry. In this regard, the main task is the development of universal tools that allow to increase the level of business entity adaptability to increased volatility of endogenous and exogenous factors which make a negative impact on the level of industrial complex economic security.

\section{References}

Afontsev, S. (2002). Endogenous Tariff Protection and the Level of Trade Distortions in Russia. Economics Education and Research Consortium, Working Paper No 01/07.

Afontsev, S. (2004). Political economy of tariff unification: The case of Russia. Economics Education and Research Consortium, Working paper.

Akerman, A., \& Forslid, R. (2009). Firm Heterogeneity and Country Size Dependent Market Entry Cost. Research Institute of Industrial Economics, Working paper 790.

Blanchard, O. J. (1981). What is Left of the Multiplier Accelerator? The American Economic Review, 150-154.

Grossman, G. M. (1994). Helpman E. Protection for sale. American Economic Review, 84(4), 833-850.

Gurvich, E. T., \& Kuznetsov, B. V. (2014). Processing industry in the structure of Russian economy during 2004-2010. Essays on Russian industry modernization: the behavior of firms. Sci. Ed.: B. V. Kuznetsov. M.: Publishing house of Higher School of Economics SRI. State University Higher School of Economics.

Helpman, E. (1995). Politics and Trade Policy. National Bureau of Economic Research, Working paper No. w5309. https://doi.org/10.3386/w5309

Idrisov, G., \& Ponomareva, E. (2015). The policy of import substitution and Russian economy competitiveness. Economic development of Russia, (10), 64-66.

Jesper, J. et al. (2003). Economy-Wide and Sector Effects of Russia's Accession to the WTO. Allied Social Science Meetings, Washington DC.

Kantorovich, G., \& Nazrullayeva, E. (2009). Specific costs in Russian industry: do direct investments lead to their reduction? Economic Journal of the Higher School of Economics, 13(1), 59-79. 
Kawai, H. (1994). International Comparative Analysis of Economic Growth: Trade Liberalization and $\begin{array}{lllll}\text { Productivity. } & \text { The } & \text { 3eveloping }\end{array}$ https://doi.org/10.1111/j.1746-1049.1994.tb01046.x

Knobel, A.Yu. (2011). Interbranch differences in the import tariff of Russia. Journal of the New Economic Association, (11), 64-84.

Sachs, J. (1993). Macroeconomics in the global economy. Prentice Hall.

Tobin, J. (1969). A general equilibrium approach to monetary theory. Journal of money, credit and banking, 1(1), 15-29. https://doi.org/10.2307/1991374

Volchkova N. The cost of WTO. Forbes. (2011). Retrieved from http://www.forbes.ru/sobytiya-column/rynki/77719-vo-chto-oboidetsya-vto

\section{Copyrights}

Copyright for this article is retained by the author(s), with first publication rights granted to the journal.

This is an open-access article distributed under the terms and conditions of the Creative Commons Attribution license (http://creativecommons.org/licenses/by/4.0/). 